In this case, ethanolic extraction did not dissolve all cereal prolamines, since the obtained extracts only contained $\mathrm{I} 8$ to $25 \mathrm{p}$. Ioo of the crude protein of the seeds. That is why we compared the results obtained in digestive contents to those of analyses, and not to the protein composition of the studied cereals.

The amino acid compositions of the extraction insolubles led us to suggest that at least one part of the prolamines that were not extracted with ethanol, was recovered in the extraction insolubles, at least in the case of maize.

Part of their aminoacids can be free or included in more or less long chain peptides in the aqueous extracts, as shown by the high amount of leucine as compared to that in the maize aqueous extract of the hydrosoluble fraction of the abomasum contents in the animals fed that cereal. Comparison of the lysine content of those two extracts does not lead to the same conclusion respecting this amino acid.

Because of the amino acid compositions of the extraction insolubles in the abomasum contents, it can be supposed that these insolubles do not contain very large quantities of prolamines.

All these results show that in the rumen there might be an important digestion of the studied cereal prolamines, but that this digestion does not lead to release of all their amino acids, and that some of them must be recovered as peptides in the rumen.

The proportions of TCA soluble nitrogenous matters were low in all cases.

The separation of the aqueous extracts through sephadex showed the disappearance after digestion in the rumen of the peak corresponding to the proteins in the case of cereals.

The large intestine contents were different from those of the abomasum because of a higher proportion of soluble nitrogenous matters in ethanol and of a lower proportion of hydrosoluble matters.

The amount of leucine in the aqueous extract of the large intestine content of the animals fed the maize diet was low and exceeded only by scarcely the half that observed in the abomasum content. This difference seems to be too large to be explained only by a dilution in other soluble nitrogenous matters of the leucine rich components in the abomasum and accounts for a disappearance of at least part of those components.

Ethanolic extracts of the large intestine contents showed an amino acid composition very different from that of the corresponding extracts obtained from the abomasum contents.

However, it seems possible, according to the relatively low lysine and high leucine amounts observed in the maize diet, that the zein found in the abomasum is diluted in other proteins in the corresponding content of the large intestine.

\title{
ÉTUde DU MÉTABOLISME DE LA MÉTHIONINE DANS LE RUMEN DE LA GHÈVRE
}

\author{
C. CHAMPREDON, R. PION et J. PRUGNAUD \\ Laboratoire d'Étude du Métabolisme azoté, \\ Centre de Recherches de Clermont Ferrand, I. N. R. A., \\ Theix 63110 Beaumont
}

A fin de connaitre l'utilisation digestive de la méthionine chez le ruminant, deux chèvres (33 et $36 \mathrm{~kg}$ ), porteuses d'une canule de la caillette, ont reçu par injection intraruminale, I h $3^{\circ}$ après la distribution du repas du matin, $2 \mathrm{~m}$ Curie de L-Méthionine ${ }^{95} \mathrm{~S}$ en présence de $2,5 \mathrm{~g}$ de 
DL-méthionine. Les animaux recevaient depuis plusieurs semaines une ration à base de foin et un concentré (orge, farine de luzerne) apportant 2,5 $\mathrm{g}$ de DL-méthionine chaque jour au repas du matin. Du sang jugulaire (cathéter) et du contenu de caillette étaient recueillis pendant les 4 jours suivant l'injection. La radioactivité totale des échantillons était mesurée au moyen d'un compteur à scintillation en milieu liquide et dans certains cas, la radioactivité spécifique des acides aminés soufrés était déterminée à l'aide d'un analyseur automatique d'acides aminés couplé avec un compteur à scintillation en continu. Les comptages de radioactivité réalisés étaient les suivants : plasma, surnageant obtenu après défécation du plasma par l'acide trichloracétique (ATC), résidu et solution obtenus après extraction des acides aminés libres du sang avec l'éthanol 82 p. Ioo, résidu et solution obtenus après extraction des contenus de caillette à l'ATC Io p. Ioo.

La radioactivité totale du plasma augmente rapidement pendant les 9 heures qui suivent l'injection, puis ne diminue que lentement par la suite. Contenue en majeure partie dans l'extrait durant les premières heures de l'expérience, elle se trouve presque totalement dans la fraction liée aux protéines $48 \mathrm{~h}$ après. Le marquage des acides aminés soufrés se trouvant sous forme libre dans le sang est faible (de l'ordre de I p. Ioo du marquage de l'ensemble de la fraction libre).

La radioactivité de la fraction soluble (ATC) des digestas augmente très rapidement après l'injection. Elle est maximale I heure environ après l'introduction du marqueur $\left(329 \cdot 10^{6} \mathrm{DPM} / \mathrm{kg}\right.$ de contenu frais) puis diminue ensuite de manière importante $\left(53 \cdot 10^{6} \mathrm{DPM} / \mathrm{kg}\right.$ après $\left.6 \mathrm{~h} 30 \mathrm{mn}\right)$. La méthionine est le seul composé qui se trouve être marqué dans cette fraction pendant la première heure, puis on voit ensuite apparaître un marquage de la cystine. Par contre, la radioactivité du résidu d'extraction augmente lentement après le début de l'expérience et atteint son maximum vers la $18^{e}$ heure $\left(206 \cdot 10^{6} \mathrm{DPM} / \mathrm{kg}\right)$; le ${ }^{35} \mathrm{~S}$ est incorporé à la méthionine et à la cyst(é)ine. Le marquage maximum de la méthionine du résidu d'extraction est obtenu 18 heures après l'injection $\left(\mathrm{I}_{43} \cdot \mathrm{IO}^{6} \mathrm{DPM} / \mathrm{kg}\right)$ tandis qu'il n'est atteint pour la cystine qu'après 24 heures $\left(\mathrm{I}_{3} \cdot \mathrm{IO}^{6}\right.$ $\mathrm{DPM} / \mathrm{kg})$.

Une proportion notable $\mathrm{du}^{35} \mathrm{~S}$ introduit dans le rumen sous forme de méthionine quitte le rumen sous forme de méthionine libre ou incorporée dans les protéines microbiennes et passe directement dans l'intestin. Le reste est métabolisé rapidement et les composés soufrés qui en résultent passent dans le sang ou sont utilisés sur place par les microorganismes pour synthétiser de la méthionine et de la cystine.

\section{SUMMARY}

\section{STUDY OF METHIONINE METABOLISM IN THE GOAT RUMEN}

In order to know the apparent digestibility of methionine in the ruminant, we injected by intraruminal way, into two abomasal fistulated goats ( 33 and $36 \mathrm{~kg}$ ), I, $30 \mathrm{~h}$ after the morning meal, $2 \mathrm{~m}$ Curie of L-methionine ${ }^{35} \mathrm{~S}$ with $2.5 \mathrm{~g}$ of DL-methionine. The animals had been fed for several weeks a hay diet and a concentrated food (barley, lucerne meal) providing $2.5 \mathrm{~g}$ of DL-methionine each day in the morning meal.

Jugular blood (catheter) and abomasum content were collected during 4 days following the injection. Total radioactivity of the samples was measured by means of a scintillation counter in lipid medium and in some of the cases, the specific radioactivity of the sulphur amino acids was determined by means of an amino acid automatic analyser connected to a permanent scintillation counter. Radioactivity measurements were the following : in the plasma, in the supernatant obtained after clarification of the plasma with trichloracetic acid (TCA), in the insoluble and solution after extraction of the free amino acids of the blood with $82 \mathrm{p}$. 100 ethanol, in the insoluble and solution obtained after extraction of the abomasal contents with ro p. IOO TCA.

The total radioactivity of the plasma rapidly increased during the 9 hours following the injec- 
tion, then decreased slowly. The radioactivity, mainly contained in the extract for the first hours of the experiment, was quite totally recovered in the protein-bound fraction 48 hours after.

Labelling of free sulphur amino acids in the blood was low (about I p. Ioo of the labelling of the whole free fraction).

The radioactivity of the soluble fraction (TCA) of digesta increased very rapidly after the injection. It reached a maximum about $I$ hour after the introduction of the tracer $\left(329 \cdot 10^{6}\right.$ $\mathrm{DPM} / \mathrm{kg}$ wet content), then decreased very much $\left(53 \cdot{ }^{\prime} \mathrm{I}^{6} \mathrm{DPM} / \mathrm{kg}\right)$ after $6.30 \mathrm{~h}$. Methionine was the only component labelled in this fraction during the first hour, then followed cystine. On the other hand, the radioactivity of the extraction insoluble increased slowly after the beginning of the experiment and reached its maximum at about the $\mathrm{I} 8$ th hour $\left(206 \cdot 10^{6} \mathrm{DPM} / \mathrm{kg}\right) ;$ the ${ }^{35} \mathrm{~S}$ was incorporated into methionine and cyst(e)ine. Maximum labelling of methionine in the extraction insoluble was obtained 18 hours after the injection ( $143 \cdot{ }^{\cdot} \mathrm{IO}^{6} \mathrm{DPM} / \mathrm{kg}$ ) whereas for cystine it was only recorded after 24 hours $\left(13 \cdot 10^{6} \mathrm{DPM} / \mathrm{kg}\right)$.

A significant proportion of the ${ }^{35} \mathrm{~S}$ introduced into the rumen as methionine left this organ as free methionine or incorporated into bacterial proteins and entered directly the intestine. The rest was quickly metabolized and the sulphur components obtained were absorbed by the blood or used on the spot by microorganisms in order to synthetize methionine and cystine.

\title{
UTILISATION DIGESTIVE COMPAREE DE L'ORGE, DE LA BANANE VERTE ET DE LA BANANE ENSILÉE CHEZ LA CHẼVRE
}

\section{PONCET}

\author{
Station de Recherches sur l'Élevage des Ruminants, \\ Centre de Recherches de Clermont Ferrand, \\ Theix 63110 Beaumont
}

Une partie appréciables des bananes vertes ne peut pas être exportée ou utilisée dans l'alimentation humaine par les pays producteurs. Or, leur matière sèche (2o p. Ioo de la matière frâ̂che) a une composition voisine de celle d'un aliment concentré, pauvre en azote (67 p. Ioo d'amidon, 3 p. Ioo de cellulose brute et 0,9 p. Ioo d'azote).

Pour étudier les caractéristiques de la digestion de cet aliment par le ruminant, nous avons utilisé des chèvres portant une canule du rumen et une canule réentrante au niveau du duodénum.

Nous avons comparé la banane verte ou ensilée après hachage à de l'orge, dans des rations ayant par ailleurs une petite quantité de fourrages verts de Pangola (Digitaria decumbens) et de tourteau de soja; le fourrage représentait environ $20 \mathrm{p}$. Ioo de la matière sèche ingérée.

Pour des quantités ingérées de 800 à $900 \mathrm{~g} / \mathrm{j}$, la digestibilité de la matière organique est élevée, comparable dans les trois régimes et même légèrement supérieure avec la banane $(82 \mathrm{p}$. Ioo contre 80 p. Ioo avec l'orge).

A ces niveaux d'ingestion ( $400 \mathrm{~g}$ d'amidon ingéré/j), la digestibilité de l'amidon de banane est quasi totale ( $99 \mathrm{p}$. Ioo pour l'amidon de banane verte, $96 \mathrm{p}$. Ioo pour la banane ensilée).

Le coefficient d'utilisation digestive de l'azote est plus faible avec les régimes de banane verte qu'avec les régimes d'orge et de banane ensilée (CUD des matières azotées totales : 54,4 p. Ioo, 78 p. I0o, 75 p. Ioo respectivement). Pour expliquer ce résultat, on peut mettre en cause l'action des tanins dont la banane verte est riche. 